This is the version of a chapter accepted for publication in Carment D., Sadjed A. (eds) Diaspora as Cultures of Cooperation. Migration, Diasporas and Citizenship. Cham: Palgrave Macmillan, pp.171-198. https://doi.org/10.1007/978-3-319-32892-8_9

Accepted version downloaded from SOAS Research Online: https://eprints.soas.ac.uk/23828/

\title{
The Influence of Diaspora Politics on Conflict and Peace: Transnational
}

\author{
Activism of Stateless Kurds ${ }^{1}$
}

\section{Latif Tas ${ }^{2}$}

\section{Introduction}

The conflict between the Turkish state and Kurds is increasing in Turkey and the neighbouring states. Societal divisions between Turks and Kurds are at a boiling point. One of the main reasons for this is that successive Turkish governments are more interested in maintaining their own power than in any real attempt at peace-making with Kurds. This chapter focuses on two interconnected arguments. First, it analyses both the ongoing conflict and also the so-called 'peace process' between Kurds, especially the Partiya Karkerên Kurdistanê (PKK; Kurdistan Workers' Party), with their imprisoned leader Abdullah Ocalan, and the Turkish state. Secondly, it explores how, without any state to their name, Kurdish

\footnotetext{
${ }^{1}$ Cite this chapter as: Tas L. (2017) The Influence of Diaspora Politics on Conflict and Peace: Transnational Activism of Stateless Kurds. In: Carment D., Sadjed A. (eds) Diaspora as Cultures of Cooperation. Migration, Diasporas and Citizenship. Cham: Palgrave Macmillan, pp.171-198. https://doi.org/10.1007/978-3-319-32892-8 9 An earlier version of this chapter was presented at the workshop on the 'Diaspora as Agents of Global Cooperation', Kate Hamburger Kolleg, Centre for Global Cooperation Research, 21-22 April 2015, Duisburg, Germany; the workshop on 'The Kurds in the Middle East: New Developments and Prospects', 24 April 2015, SOAS London Middle East Institute (LMEI), University of London, UK; and the workshop on 'Diaspora Mobilisation for Conflict and Post-conflict Reconstruction: Comparative and Contextual Dimensions', 26-27 November 2015, University of Warwick, UK. It is an expanded version of a paper that was previously published in Open Democracy entitled "What kind of peace? The case of the Turkish and Kurdish peace process", see Tas (2015). This chapter was also published as an article in the Review of Social Studies (RoSS), in 2016.

2 Latif Tas is a Marie Sklodowska-Curie Global Fellow at SOAS, University of London. Previous posts include a Research Fellowship at Wissenschaftskolleg zu Berlin (Forum Transregionale Studien, Humboldt University) and Researcher and Consultant with the Oxford Diasporas Programme, University of Oxford. He obtained his PhD in Law from Queen Mary, University of London. His book, Legal Pluralism in Action: Dispute Resolution and the Kurdish Peace Committee, was published by Ashgate in 2014. He is an inter-disciplinary scholar working on transnational law and migration, gender, diaspora mobilization, and conflict and peace in Europe and the Middle East. His current research project has received funding from the European Union's Horizon 2020 research and innovation programme under the Marie Skłodowska-Curie grant agreement No 703201. SOAS, University of London; Syracuse University (New York); and MPI for Social Anthropology (Halle) are hosts of this new research. Contact Email: e-mail: latiftas@yahoo.com
} 
diasporas - both in Turkey and outside-have become increasingly active agents. The links that Kurds in the diaspora have with the international community are described. The effects of these links not only on the conflict, but also on potential roles of 'peace-making', 'peace-building', and 'reconciliation' processes within Turkey, are discussed. The chapter challenges Benedict Anderson's idea that those who live in diasporas keep themselves safe and avoid personal sacrifices (Anderson 1998). Instead, it is suggested that diasporas can be an active part of both peace and conflict. The research reported here suggests that stateless diasporas can provide a training ground for institutions serving potential future states.

\section{Methodology}

In order to explore individual and family Kurdish experiences in different diasporas, and their involvement in homeland politics, conflict, and peace, I carried out multi-sited ethnographic qualitative research (as described in Marcus 1995) between December 2012 and February 2016. This included four focus groups and 52 in-depth, open-ended qualitative interviews involving individuals originating from different Kurdish regions, but now living in different part of the diaspora. The research involved a total of 85 Kurdish adults, of whom 45 were women and 40 were men. These individuals were currently living in the UK (London), Germany (Berlin) or Turkey (Istanbul and Diyarbakir). Research participants included community representatives, political and women's rights activists, MPs, co-mayors, academics, journalists, and lawyers.

This builds on work I have conducted on Kurdish diaspora organisation and practices in the UK, Germany, and Turkey, and their transnational connections since 2008, as part of my previous research (Tas 2013a,b, 2014). In addition, reports from different NGOs, brochures and publications from different Kurdish associations, including PKK were examined; events, seminars, and conferences were followed; and speeches and interviews from different Kurdish and Turkish political and military leaders were analysed.

I want to begin by arguing that there is no real peace process in Turkey. The outcomes of the research reported here show that the aim of negotiations - for both the ruling Justice and Development Party (AKP) and the PKK - is actually to monopolise power and violence, rather than to move towards peace. I argue that this 'game' based so-called 'peace process' has further deepened divisions between Turks and Kurds, and opened the door for an escalation of violent conflict. The second argument is that diasporas, especially for stateless people, are not just 'a home away from home'. Forced migration, unequal citizenship, and an unsafe living environment mean that even an ancestral homeland can feel like a 
diaspora. For this reason, stateless diasporas are not only idealistic protesters, but can also act as positive agents for the homeland and create practical solutions for stateless communities.

\section{The current conditions and crisis}

The first sign of the failure of the most recent so-called 'peace process' was seen on 6-7 October 2014 in almost all Kurdish-populated cities in Turkey. Around 50 people lost their lives (Daglar 2014; Pope 2014). Escalation of the conflict between June 2015 and February 2016 has additionally cost more than a thousand lives. As in conflicts over the last three decades, most of these individuals were Kurdish civilians. Several towns have been under 24-hour curfew for months (Amnesty International 2016; Pitel 2016). This means that civilians either starve or face sniper fire. The UK Green Party (2016) Leader Natalie Bennett described the situation:

Kurdish communities in eastern Turkey have been placed under so-called curfews, some for long periods, which has made it impossible for families to secure food supplies, threatened their access to water and electricity and denied those in need access to medical treatment. Amnesty International has described this as being like 'collective punishment' of these communities.

More than one million people have been affected. 200,000 people have been displaced, some of whom are trying to make their way to Western Europe. There is not only a lack of any substantive progress towards peace, but a worsening of the situation. The conflict has spread all over Turkey. In addition to conflict in the Kurdish regions, between June 2015 and February 2016 there were five big explosions in Diyarbakir, Suruc, Ankara, Sultanahmet, and again in Ankara; and 234 people were killed and thousands of people were injured as a result of these explosions that, it has been claimed, were carried out by Islamic State in Iraq and Syria (ISIS) militants (Karaca 2016). If these attacks were not the result of Turkish state intelligence collaboration, then there was at least a total intelligence failure on the part of the Turkish state to let these almost similar attacks happen. The majority of victims from the first three attacks were Kurds. The fourth explosion targeted German tourists, while the fifth was directed against Turkish military personnel (Letsch 2016). Following each attack, Turkish President Recep Tayyip Erdogan claimed how Turkey is determined to continue its fight against those who carried out the atrocity and the powers behind them.

However, Erdogan has used these ISIS attacks, which have mainly killed Kurds, as an opportunity to start a war; not against Islamic militants, but instead against Kurds in Turkey and Syria (CBC 2016; RT 2016; Tisdall 2016). Instead of retaliating against ISIS militants, Turkey and President Erdogan are once again 
repeating their old and unsuccessful methods, explicitly aiming 'to annihilate' the Kurdish militants and their supporters (Cakan 2015). Making Kurds the scapegoat is always popular among Turkish nationalists and populist politicians who court the nationalist vote. Doing so also represents an opportunity for the state to divert attention away from the country's major problems. While Erdogan desperately needs to use this card, the PKK also uses Erdogan's anti-Kurdish policies to increase Kurdish nationalism for his own hegemony. Within both Turkish and Kurdish societies it has almost become a crime to be anti-nationalist. These developments support the idea that, for both the Erdogan-led AKP government and PKK, the socalled negotiations were not about risk-taking to make peace-but about risk-avoidance to maintain the status quo, and so to maintain the current actors' grasp on power. However, without taking substantial risks, including the risk of losing power, it is effectively impossible to broker peace (Dogan 2016).

Before analysing the current conditions in the Middle East and Turkey, and the role of diaspora communities in more depth, I would like to underline that peace negotiations are never easy. Getting started is often-usually-the most difficult thing to do. Conflict will either be temporarily and conditionally stopped, or may even be continuing (Sumbeiywo 2008). Every peace process is like a piece of theatre. There are many players, actors-from different sides-who do not trust each other. Of course, the different sides have different agendas. Some protagonists may be benefitting directly from the war, and can easily choose to destroy any possible peace process. For example, the 50,000 men currently employed by the Turkish state as village guards have no incentive to support peace, since peace will probably mean that they will lose their family's livelihood. Losing their job would also mean losing the weapon they rely on to 'defend' themselves (Geerdink 2014). Other people may want to be perceived as peace-makers, but only so that they can monopolise power and violence for their own benefit. It is even more difficult when there has been a long war, with trust lost between parties and societies. This is the Turkish, Kurdish, and Middle Eastern situation.

With Kurdish populations living in their historical regions in Syria, Iraq, Iran, and Turkey, as well as in the diasporas, one cannot separate the Kurdish and Turkish 'peace process' from ongoing conflicts and wars in the neighbouring countries. Many of the Kurds I interviewed believe that for any successful and permanent peace, Kurds living in all of these places, including the diasporas, must be involved in the peace process. There is an international historical context, with effects on international stability and important human rights issues to consider. These all mean that there is a wider international responsibility to observe, oversee, and to take an active part in the peace process. 


\section{Where is the diaspora for stateless people?}

In this chapter, I am using the word 'diaspora' to mean both a place and group of people. I have already discussed elsewhere (Tas 2014, 2016) that for stateless people, diaspora is not just the 'home away from the original homeland' or 'dispersal of people from their original homeland' described by many researchers (see Connor 1986; Safran 1991; Tölölyan 1994; Cohen 1997; Palmer 1998). Forced internal migration can create a diaspora within a nation-state. Continuing state oppression, weak citizenship, differential minority classification and treatment (Ustundag 2016), and an unsafe living environment all mean that even the ancestral homeland can feel like a diaspora. For that reason, stateless Kurds do not just have one diaspora, they have double or even triple diasporas. For example, a Kurdish family from Diyarbakir may feel as though they are living in a diaspora. When they are forced to move to Istanbul, they are living in a double diaspora. After they migrate to London or Berlin, they are in a triple diaspora. All places feel temporary for them.

The resulting very limited feelings of belonging contribute to increasing mobilisation among the diasporas. Around four million Kurds have already been internally displaced in Turkey, and more than one million Kurds from Turkey have moved to Western Europe. Even more are, and will be, affected by the ongoing conflict in Turkey and the Middle East. The Western world, especially European countries, has turned a blind eye to oppressive and totalitarian leaders such as Erdogan in the hope that they will not receive any further refugees and may assimilate those they already have. However, it is the discriminatory policies of these oppressive leaders that have created the forced migrations in the Middle East and Turkey in the first place. As long as war, conflict, and crime continue as a result of their policies, the tidal wave of more refugees will continue to flow. A recent study by Bosphorus University, Istanbul showed that more than 30 percent of people from Turkey, around 25 million, would like to leave the country because of ongoing political instability (Cumhuriyet 2016).

In the last 35 years, there has never been a day without war and violence in the Middle East and Turkey. The most recent conflict-which started in March 2011 in Syria, has included Iraq from 2014 and Turkey from June 2015-has cost around 500,000 lives. It has created more than 11 million homeless refugees (BBC News 2016). It is not surprising that all of these wars have disproportionately affected Kurds. Kurdish statelessness is a key reason for the direct and indirect discrimination against Kurds in the various nation states they live in. 
In Syria and Iraq, there is currently no rule of law, no consistent authority and, effectively, no state. The Iranian and Turkish states have their own agendas. They are both aiming for a 'big brother' style leadership of the Middle East using, respectively, Shia or Sunni proxies. Neither Iran nor Turkey wants to see Kurds united: since the sixteenth century both are accustomed to using warring Kurdish factions as buffer armies. When Kurds try to move away from this situation, and connect with the international community, then the Iranian and Turkish states try new ways to weaken Kurds and keep them divided. Most recently, at the same time that Turkey was supporting the ISIS against Kurds in the Middle East (Sanchez 2016) and using state violence against Kurds in Turkey, Iran was directly helping and supporting Shia militias fighting in Iraq against both Kurds and the IS. Both countries are happy to see Kurds divided. There is a famous phrase that says, "if you find two brothers fighting, do not try to separate them, otherwise they will both turn on you" (Sumbeiywo 2008). In the Kurdish case, other countries do not just leave Kurdish factions to fight each other, they add fuel to the flames to make sure that the fighting continues.

\section{The history of the Turkish-Kurdish 'peace processes'}

All these issues and 'big brother' games demonstrate why it is difficult to talk about any real peace process between Turks and Kurds. There have been some talks about possible peace talks. These limited talks have not involved all the different internal and international stakeholders. Instead, they have only been between two political parties or groups (AKP for Turkey and PKK for Kurds). Talks about talks are not new. Around two decades ago, in 1993, the Turkish President Ozal tried to negotiate with the PKK leader Ocalan through various mediators (Ensaroglu 2013; Tas 2015). At around the same time, conservative Prime Minister Suleyman Demirel, during a visit to Diyarbakir, said that Turkey "recognised the Kurdish reality". Following these positive moves, on 20 March 1993, just a day before the Newroz (Kurdish New Year) celebrations, the PKK declared their first-but not their last-ceasefire.

However, these positive movements did not last and the one-sided PKK ceasefire ended in June 1993. This failure opened the door for the very brutal conflicts of the 1990s. The importance of the 'Kurdish question' was acknowledged in 1995 when a progressive Turkish politician, the ex-Prime Minister Mesut Yilmaz, declared that democratisation in Turkey and EU accession could not be achieved in Ankara until the problems in Diyarbakir were resolved. In 1997, Turkish Prime Minister Erbakan made another unsuccessful attempt-one of the results of which was a military coup.

The 'Kurdish question' moved beyond Turkey to become a European and international issue with the capture of the PKK founder and leader, Abdullah Ocalan, in 1999. After this arrest the PKK and many 
Kurdish leaders were initially paralysed. Until 2004, the PKK were effectively militarily silent. However, this was socially, politically, and legally one of the most active times for Kurds and the PKK. According to many of my interviewees in Turkey, Berlin, and London, Kurds and the PKK started to learn about the dynamics of international power, and focus on international politics.

The PPK recruited a new cadre of members and reorganised the approach to armed struggle against Turkey. Perhaps even more importantly, the PKK focused on creating social, legal, and economic institutions in Turkey, Syria, Iraq, and the different diasporas. These institutions were intended to contribute to a possible future Kurdish state, as discussed in a later legal case-study. Transnational Kurdish mobilisation was created and links were made between different capitals, including Diyarbakir, Istanbul, Berlin, Brussels, London, and Paris. Different political parties, associations, and unofficial legal courts were created and developed during this militarily silent, but institutionally very active, period. Although PKK was listed, and so banned, as a terrorist organisation by many states; political, social, and economic mobilisation continued.

During the same time period, with Ocalan under arrest and PKK militarily quiet, Turkey felt able to relax militarily. However, the effect of the long war with Kurds paralysed Turkey socially and economically. Seeking help from the economic crisis, the focus was on achieving EU accession. Turkey promised to meet the Copenhagen Criteria, and in response, Turkey's candidacy was approved in Helsinki in December 1999. Many important constitutional amendments were passed by the Turkish parliament following Ocalan's arrest, including the abolition of the death penalty and of the state of emergency (Tezcur 2010).

In 2002, after a decade of coalition government, the AKP achieved an electoral majority and were elected, under the leadership of Recep Tayyip Erdogan. Despite the moves towards democratisation, there were no specific constitutional changes recognising the existence of Kurdish ethnicity or language. No positive rights are accorded to Kurds. Instead, thousands of Kurds are in prison. Deaths in custody, extrajudicial killings, forced migration, and unequal societal treatment all impact Kurds disproportionately. Ryan (1994) and Wickham Crowley (1994) claim that democratisation can reduce the capacity and organisation of insurgent movement. This is not so if the so-called improvements are shortterm and cosmetic, as is the case for Kurds in Turkey. As long as the underlying reasons for starting rebel movements continue, mobilisation and further radicalisation of that movement also continues. Kurds are forced to live in diaspora condition with unequal citizenship. Kurdish regions were not supported with economic development, and unemployment still remains very high. Silence from the PKK allowed the Turkish state and government to continue to 'wait and see' and apply the old methods of ignorance and assimilation, 
under the guise of a process of so-called democratisation. Only after the PKK restarted the war on the Turkish state in 2004, did the AKP remember that they have a 'Kurdish problem'. In August 2005, Prime Minister Erdogan claimed that 'the Kurdish problem' was his problem and that he would resolve it through democracy (Yavuz 2009). But very little in the way of resolution was done in the following four years.

In 2009, the AKP opened a public debate about a 'Kurdish opening'. After criticism from Turkish nationalists, including AKP members, this was renamed as a 'democratic opening'. Even this title was too radical for nationalist Turks, and the initiative was rebadged as 'the national unity and fraternity project'. Even though the Erdogan-led AKP had a dominant majority, it was difficult to even decide on a name for negotiations. However, Kurds and some Turks were still hopeful for peace.

Eventually, in late 2008 and the beginning of 2009, with the help of Norway and the United Kingdom, and for the first time in history, Turkish state representatives and the PKK, working alongside members of the Kurdish diaspora in Europe, had direct meetings and peace talks in Oslo. This is now called the Oslo Process. However, this peace attempt could not be sustained. The Turkish government and the PKK each blamed the other for the collapse of the talks in 2011, after the minutes were leaked to the media, and the process was made public (Philips 2015). The broken promises and loss of hope after Oslo were followed again by some of the bloodiest conflicts between Turkish state forces and the PKK since before the 1999 Abdullah Ocalan arrest (Tezcur 2013). The Uludere massacre took place in December 2011, when 34 Kurdish civilians were killed by the Turkish air force (The Economist 2012; Al-Monitor 2013; Goel 2015). This escalated the conflict. Following this, Ocalan's meetings with his lawyers and other visitors were cancelled. PKK prisoners in Turkey took part in lengthy hunger strikes at the end of 2012.

During this crisis I carried out fieldwork research in Germany. This included meeting and talking with Sakine Cansiz in Berlin, in December 2012. She was one of the founding members of the PKK and a prominent leader within the Kurdish women's movement. We discussed the conflict and the poor prospects for peace, just a few weeks before she and two other female Kurdish political activists were assassinated in Paris (9 January 2013). The murderer's links with the Turkish Intelligence Service (MIT) have been confirmed (Cumhuriyet 2015; Demir 2015). Despite the bloody war, 67 days of hunger strike, and the Paris assassinations, there was another step towards peace when Ocalan's ceasefire message was read during the Newroz 2013 celebrations in Diyarbakir. The PKK and Ocalan openly declared that 'peace process' negotiations were going on. This time the process was named the 'Imrali process', after the island where the imprisoned PKK leader, Ocalan, has been jailed since 1999. However, the Erdogan-led AKP government claimed for a long time that it was not the government but the state that was in contact with 
Ocalan and other Kurdish political representatives. This was an attempt to protect the AKP from any damage resulting from this process. They were avoiding, rather than taking, any risks. As Candar (2015) states, the peace process in Turkey between Turks and Kurds was neither transparent nor mediated by a third party. The AKP government attempted to assert its strength by neglecting to include any independent parties, and this damaged the structural viability of the process. Candar (2015) is clear that the "Kurdish issue has become an electioneering tactic on the part of the AKP and therefore any current peace process efforts would be lacking in substance and drive".

\section{Unbalanced 'peace processes'}

In 2009, the Turkish President Abdullah Gul claimed that "Good things are going to happen" (Turkone 2009), referring to the Kurdish issue, and acknowledging it as Turkey's most important problem. However, seven years after the 2009 Oslo talks, there have still not been any substantive developments. Despite the talks between Ocalan and some key players, including some Kurdish MPs, the Turkish Intelligence Service, and some AKP members, no 'good things' have happened. The current Turkish President Erdogan has been the unchallenged leader of both AKP and Turkey since 2002. He has consistently avoided, at least openly, either being part of the process or even working to move the process on.

The primary issue on Erdogan's agenda has been to promote his personal unchallenged power. This is why he was so keen to change Turkey from a parliamentary system to a presidency. However, after Selahattin Demirtas, the co-leader of the pro-Kurdish Peoples' Democratic Party, the HDP, declared in March 2015 that "we will not make you the president" (Hurriyet 2015), then Erdogan focused on playing the Turkish nationalist card. In April 2015, in direct contradiction of his 2005 Diyarbakir speech, he claimed that, "Turkey has no Kurdish problem". The following months, he restarted the war against Kurds in Turkey and started a Syrian offensive.

When a peace process only involves a few of the parties to the conflict, and leaders are only concerned with their self-interest, it is not surprising that the results are as observed in the Turkish-Kurdish peace process. If peace negotiations are to be successful, and not rely solely on military action, the different parties must work together and be prepared to take risks to solve the dispute. Without a clear roadmap, a specified timetable, the involvement of all key stakeholders and interested third parties, plus international involvement, it is not possible to even start to resolve the differences between sides who have been in conflict for a long time. Neither key actors within different civil entities, nor all the various relevant political parties knew the details of negotiations between the imprisoned Kurdish leader and the 
AKP or state representatives. There was no clarity about the peace talks themselves, the possible reconciliation process, or possible new institutions in the formation of a potentially decentralised Turkish state. As we have seen in the Turkish-Kurdish case, empty promises in relation to this sort of so-called 'peace process' almost always open the door for brutal conflict. This is exactly what led to the conflict that started in June 2015. By February 2016, after only eight months, the conflict had cost around one thousand additional lives.

Even if a peace process was successfully developing between the PKK and AKP then, in the long term, the exclusion of the other factions might well increase the possibilities of conflict. For example, Kurdish Hezbollah could turn their guns onto the Turkish state, saying that they do not recognise any peace process, and that they want to fight for an independent Kurdish or Islamic State. Similarly, Turkish nationalists and former members of the Turkish military have not supported any moves towards peace processes with Kurds, including the most recent one. Instead, they have been championing more oppressive types of military operation in Kurdish regions (Yavuz and Ozcan 2007; Gocek 2011).

All previous negotiations were unbalanced. On one side of the imagined 'peace process' was the government of the Turkish state, on the other, an imprisoned leader under the control of that government and the state. Messages from Ocalan about the negotiations were delivered by a few selected Kurdish political party members. Research about peace and conflict (See Laderach 1997; Wessels 1998; Zartman 2007; Harbom and Wallensteen 2008; Bercovitch 2009; Loizides 2009; Ramsbotham et al. 2011; Hamber 2015) suggests that, at the beginning, any peace process should be limited to only a few actors. But in the Kurdish and Turkish context there has been no substantive process over the last seven years. After all this time, we still do not even know whether there are any mutually agreed principles, and what they might be. There has not been an Observatory Committee. No Truth and Reconciliation Committee had been established until the day of completion of this research. There has been no involvement from the UN or European Union, or other parts of the international community. Nor is it clear who might be the guarantor of any potential peace. Millions of people have suffered and have been forced to move to internal and external diasporas, as discussed above, because of the ongoing conflict.

Understandably, both the migrants and those people who have not moved have very little trust in the ongoing so-called peace process. All this makes both any talks and the overall peace process itself very fragile. The politics of the Middle East are extremely dynamic. Individual players and factions frequently swap allegiances (Rosenberg and Wolfsfeld 1977). It is therefore important that any peace process should include all main actors and factions (Lederach 1997; Zartman 2007; Ramsbotham et al. 2011). 
Kurds and Turks can only continue living together if there is a peaceful solution to the ongoing conflict. Even hope for peace cannot continue if promises remain empty. Each new episode of violence acts as a reminder of the previous bad experiences and further increases hate between the different ethnic groups, making it more difficult for future generations to come together and make a durable peace. The recent wars with Kurds in Syria and Turkey will produce new developments, and may even challenge borders in the Middle East, including Turkey. Kurds have moved on from their old method of armed struggle against Turkey into societal resistance. They have named Turkey as a 'coloniser' or 'occupier' state. With the help of the transnational Kurdish diaspora, they have made the Kurdish issue into an international issue, and so brought the Kurdish case to a similar level as the Israeli and Palestinian conflict, as discussed in more detail by Darweish and Rigby (2015).

\section{Diaspora is not a safe haven}

The underlying concern here is how to work towards successful negotiations for peace, including a stable post-conflict situation, with the help of Kurdish stateless diasporas. There is a large literature on diaspora, conflict, and peace (see for example, Lederach 1997; Al-Ali 2007; Snyder 2015). One can easily observe deep differences between and within diasporic communities. There is a strong emotional connection between society in Kurdish regional homelands and Kurdish diaspora communities. As in the Kurdish homelands, diaspora societies are not a unitary or homogenous entity. Religious and ideological divisions exist within Kurdish society.

War and conflict over the past 30 years have forced hundreds of thousands of stateless Kurds to flee their homelands in Turkey and other countries in the Middle East in an attempt to secure safety outside of the region. Many of those who have moved to Western Europe experience continued feelings of alienation, with only limited feelings of belonging to their 'host countries', and a frequent sense of living in limbo. These sentiments have been an important engine of Kurdish nationalism, mobilising Kurdish men and women in the diaspora to bring an end to their perceived statelessness (Tas 2015, 2016). The diaspora is seen by many as a safe environment within which to organise: creating not only "longdistance nationalists" (Anderson 1998, 2006; Sheffer 2002; Schiller and Georges 2001; Schiller 2005) but also alternative institutions for a future, imagined state. It can be argued that statelessness, diasporas, and nationalism are strongly connected in so far as statelessness and diasporas can be seen to feed nationalism. Since Kurds have no 'unitary' religious or linguistic identity, many Kurds have claimed that the only way forward is to become much more nationalistic. From this perspective, unity through nationalism is the only way to end Kurdish statelessness and to make a stable peace. 
Many Kurds believe that Kurdish people, both as individuals and as a community, have not been 'strong enough' nationalists, since they have not been successful at establishing their own state. The weak nationalism of stateless people, including Kurds, has been part of academic debate in recent years. For example, Ismail Besikci, a well-known Turkish academic who has researched Kurdish issues for decades, has asserted that, "Kurds are not good enough nationalists. They should not be as democratic as they are today. It's too much. It is not Kurds' business to make Turkey a more democratic country" (Besikci 2014; Hamsici 2014).

Abdullah Ocalan, the leader of the PKK, who has been imprisoned by Turkey since 1999, has also called on all Kurdish people around the world to unite, and to show resistance against their enemies (Constanze 2014). Kurds who have left the various imagined homelands of Kurdistan to live in diasporas, often take such calls for national solidarity especially seriously. The IS attack on Kobane (Rojova, North Syria), which has cost thousands of lives and caused suffering to hundreds of thousands of people, is the first time in history that Kurds from different parts of the world have joined together to fight for the same cause. These efforts demonstrate a significant shift in Kurdish nationalism: from localised and weak nationalism towards a collective, stronger form of nationalism with the help of diaspora mobilisation. However, some other Kurds argue against stronger nationalism, and instead believe that Kurds need to be more democratic than they are currently. Abbas Vali, another well-known Kurdish academic, said that, "I have to fundamentally disagree with Besikci. Kurds are not democratic enough" (Vali 2015). Kurds who want to promote a more advanced form of democracy are especially concerned about the rights of women and other powerless groups. They even want to champion the right to be heard for those people who hold political views in direct opposition to their own.

Because of long years under the assimilationist policies of the Turkish state, then until recently many Kurds have felt ashamed of their cultural identity. Many Kurds hid their Kurdishness and Kurdish roots (Tas 2014). However, with the recent conflict in the Middle East and, especially, the victorious fighting in Kobane, then more Kurds are now becoming increasingly proud of their Kurdishness. Linked to this, there is increasing Kurdish nationalism. As Kurds are still an underdog minority, this nationalism is developing into an 'aggressive' form which has even been described by Bozarslan (2015) as 'narcissistic nationalism. ${ }^{3}$

\footnotetext{
${ }^{3}$ The term was used first time by Sigmund Freud (1856-1939) appeared in his work "Civilization and Its Discontents (1929-30), in relation to the application of the inborn aggression in man to ethnic (and other) conflicts.
} 
Members of the Kurdish diaspora have for many years tried to remove the Kurdistan Workers' Party (PKK) ${ }^{4}$ from the European Union's list of designated terrorist groups (Channel Four News 2014). ${ }^{5}$ Freedom for Ocalan is another key goal of the Kurdish national diaspora movement. These movements are organised under the banner of the Kurdish National Congress (KNC). This was established on 24 May 1999, just a few months after Ocalan was arrested. Underlining the importance of the diaspora communities, the KNC is based in Brussels. This is a temporary arrangement which will last until Kurds have full independence, or at least substantive autonomy.

Under the KNC banner, Kurdish transnational political and protest movements in Europe have made the world aware of the effects of ISIS attacks against Kurds in Shengal, Iraq and Kobane, Syria as well as Turkish state violence against Kurds in Turkey. I believe that Benedict Anderson (1998) is wrong when he claims that members of diaspora communities try to influence what is going on in their homeland without being physically involved in destructive conflicts. As part of my ethnographic research, I was told that thousands of young Kurdish men and women have travelled from London, Berlin, or Istanbul to fight, and help the Kurds in Turkey and Syria. Some of these people are well-educated or work in well-paid professions. Even some of those who remained in their new host countries, or as internal migrants within Turkey, have been arrested for demonstrating their support for the Kurdish cause.

People from the diaspora who cannot go to fight themselves, instead organise fundraising events and take part in lobbying activities and demonstrations with the aim of persuading British and European politicians to help the Kurdish movements in Turkey, Iraq, Syria, and Iran. For example, in September and October 2014, some London based Kurds even went on hunger strike for the Kurdish cause. Between June 2015 and January 2016, thousands of Kurds in different diasporas carried out demonstrations and organised petitions against anti-Kurdish state operations by Turkey. Some of these Kurds have been criminalised by the British or Turkish state (See also, Baser 2015; Garmiany 2015; Telgraf 2016).

Kurds are no longer just a local tribal group, operating through kinship networks. The Kurdish lobby in the diaspora may not be as strong as that for Armenians and Jews, but they are moving in that direction (Barzani 2014). Millions of Kurds and their supporters can, and do, take to the streets of Istanbul, Berlin, London, Paris, New York, and Brussels, whenever there is an issue of concern. They also have increasingly

\footnotetext{
4 The Kurdistan Workers' Party, Partiya Kărkeran Kurdistan (PKK) in Kurdish, began operations against the Turkish State in 1984. Since then more than 50,000 Kurdish and Turkish people have died as a result of the conflict.

${ }^{5}$ The European Union first listed the PKK as having 'been involved in terrorist acts' in 2002. It reaffirmed its position in 2011. Available at: http://eur-lex.europa.eu/legal-content/EN/TXT/?uri=OJ:L:2011:028:TOC [accessed 04.01.2015].
} 
strong and close relationships with the governments of their new host countries. For example, Kurds regularly use facilities within the UK parliament for meetings and political discussions, and several MPs and Lords usually input favourably. These increasing links should not be underestimated.

As we have seen, diaspora communities can easily become a driving engine for homeland politics, nationalist movements, and even armed conflict in the original homeland. They can also become an agent involved in putative peace processes. As discussed above, this was the case for the peace process between the PKK and Turkish state representatives, especially the Turkish National Intelligence Service. In 2009, initial negotiations were brokered with the help of diaspora representatives, in the so-called 'Oslo Process'. This example demonstrates that the Kurdish stateless diaspora has already been an active, influential actor in policies affecting its homeland. As one of my interviewees explained, in November 2014:

If there is going to be any peace with Turkey, it will be down to the diaspora. And that's true for conflict too. We are becoming as strong as the Armenian and Jewish diaspora. Assimilated Kurds in Turkey cannot make peace-or war-without us. We [diaspora Kurds] have suffered. And we [diaspora] will be a part of the decision-making process, if there are going to be any decisions.

A Kurdish academic from London stated that without 'true Kurds' at the peace table, it is not possible to make peace for Kurds. He describes what he means by 'true Kurds':

There are many false Kurds in Turkey and elsewhere. They have been assimilated under a host identity and can only think about their own personal needs, and the importance of their hosts. For example, the Turkish former presidents Ismet Inonu and Turgut Ozal, and other politicians who are involved in mainstream Turkish political parties, like AKP and CHP, might claim that they are from a Kurdish background. But for the whole of their political life, they have worked for the Turkish state. These sorts of people cannot and should not represent Kurds. Another group of false Kurds are those who try to make small changes to Turkish political structure, and so to claim a few minority rights for Kurds. They also don't represent Kurds. Ocalan himself can now be considered as falling into this group, since he has sacrificed the aim of Kurdish independence, for a few baubles. But I can forgive him because he is in Turkish prison. True Kurds are fighting for full Kurdish independence, or at very least, equivalent rights as the Turks have. Only these true Kurds deserve a place at the negotiation table. 
This non-negotiable and hypernationalist view can be seen among many forcibly displaced stateless diasporas. Many people like this have very little trust in any so-called 'peace process'. As stated earlier, all of this makes any talks and the peace process itself very fragile. Many of my interviewees do not trust the Turkish state, especially the Erdogan-led government, to make peace. Another of my interviewees explained in London, January 2015:

Of course we [diaspora Kurds] want peace. Who would not want peace? I have lived in three different diasporas in the last 30 years: In Germany, in France and now in the UK. I haven't seen my hometown or my relatives in Turkey since the 1980s. My land was occupied by the village guards. Peace may help people like me to end this misery and to have their land and their home back. But Turkey is not serious about making peace. Erdogan is just playing with us. He needs Kurdish votes and he has used us to stay in power since 2002. He has not made any legal changes in favour of Kurds in his last 13 years in power. He is not a friend of Kurds. We [Kurds] have to think beyond any national borders to help each other. We cannot trust others to help us to make peace; we should create our own state and pull down all the borders that divide us.

The imprisoned Kurdish leader, Ocalan, understands what a potentially important role diaspora communities have. He has repeatedly asked the diaspora to contribute to the development of the peace process both by organising discussions and other events, and also involving European institutions and governments in these events. With this in mind, several conferences (May and December 2013, December 2014) were organised in Brussels by the Kurdish National Congress in the Diaspora (KNK- Kongreya Neteweyî ya Kurdistanê).

At the 13th General Meeting of the KNC, held in Brussels on 25-26 May 2013, it was stated in their concluding brochure that Kurds have the right to live and create their own destiny in their own land as a Kurdish nation, and:

Democratisation of [the] Middle East can be achieved through the recognition of Kurdish identity and Kurdistan as a nation... On these grounds Kirkuk and other parts of [the] Kurdish region[s] that were taken [by Turkey, Iraq, Syria and Iran] have to be included again in the map of Kurdistan, and these countries have to show their respect for the map of Kurdistan and its territory.

As we see from this explanation, there are no signs that Kurds, as represented by the PKK and KNK, have dropped their claim of creating a unitary Kurdish state. The Turkish President Recep Tayyip Erdogan has also pointed out in many speeches how various Kurdish power-holders, and especially diasporas, play a 
crucial role in the ongoing conflict and its resolution. The Kurdish diaspora is therefore recognised as an important influencing factor by both sides of the conflict.

\section{Kurds are at last learning to play the system}

More tactically, and perhaps more realistically, many Kurdish nationalists have temporarily postponed their aim of creating a Kurdish state in Turkey, as they focus on state-making in Syria and Iraq. One Kurdish legal practitioner in Istanbul, who also functions as a Kurdish politician, said in November 2015:

Ironically, Kurds have to be thankful to Erdogan and the Turkish state's recent ill-considered internal and foreign policies against Kurds. These have shown the authoritarian face of Turkey to the world and the real extent of discrimination. This has helped Kurds to increase their power. They now control a large area in Syria, and even control some cities in Turkey. Kurds are strengthening connections with various international powers and getting increasing Western support. So I want to see Erdogan in power a little longer. His aggressive policies may actually help Kurds to establish the independent state we have been dreaming of for such a long time.

As long as the fight continues in Iraq, Syria, and Turkey, the most radical Kurds can consolidate their increasingly radical members around that struggle. As Jok says for the South Sudanese case: “nations don't just happen-they have to be planned, forged and crafted" (Jok 2012). Many Kurds in diaspora and also in Turkey are aware that the processes and techniques for state-making are not easy and may take a long time. For example, the Mayor of Kobani acknowledged that, "we [Kurds] are not professional [yet] when it comes to independence" (Abdi 2015). Cemil Bayık, one of the founders and leaders of the outlawed PKK, has said that:

When the chaos that is engulfing the Middle East is taken into consideration, disarming is not possible... Ankara should change its stance against the Kurds... Turkey should develop peaceful political and economic relations [with Kurds]... Direct communications should be established between [imprisoned PKK leader Abdullah] Ocalan and Kandil [mountains where the PKK militants are based]. And finally, the negotiations should officially be launched. If all these conditions are applied, then our arms might be silenced (Today's Zaman 2015).

Many of my interviewees believe that the sort of democratic autonomous system that Ocalan and many Kurdish nationalists currently support for Turkey would not only give time but also allow some of the necessary preparations for a future unitary Kurdish state. Kurds already practice their own legal system 
de facto, for business, family, and even criminal cases, as part of their practical resistance against the Turkish state and institutions of the state. This is also part of the Kurdish state building project which has been redeveloped and introduced by the PKK for Kurdish people wherever they live, including the UK and German diasporas (Tas 2013a,b, 2014). I discussed 25 cases from a diaspora court in my previous book (Tas 2014), and there showed how the Kurdish diasporas have not only carried out demonstrations or lobbying for their homeland, but also worked towards alternative institutions for a future Kurdish state.

\section{Conclusion}

Peace negotiations between Turkey and Kurds have never been balanced. Messages from Ocalan about any negotiations are carried only by a few selected Kurdish political party members. Although any peace process must necessarily be limited initially, with only a few actors, there seems to have been no substantive process over the last three decades. Many important Kurdish and Turkish entities, including the diasporas, have never been included in any substantive way. Diaspora, for stateless people, is not only a place outside of their country of origin, but can include their ancestral village or city, when insecurity and inequality continue there. For that reason, Kurds living in diasporas will continue to be active locally and internationally. This will not just affect Turkey but many other Middle Eastern and European countries until Kurds have some secure place where they are treated as full citizens.

Kurdish diaspora communities are the result of, and key actors in any, conflict. They have acted not only as an important driving engine for homeland politics, but also as a way forward to peace and to the development of future Kurdish institutions. Some elements in Kurdish diasporas have recently promoted a 'strong' and even 'aggressive' nationalism. These contradictions may be an important barrier for Kurdish leaders to overcome if there is ever going to be peace.

Turkey, since its establishment as a republic, has never achieved social cohesion. The conflict between Turks and Kurds is one of the major reasons for this. The Turkish state has not tried to make peace in any real way, merely reiterated attempts at military 'solutions'. These have not moved forward now. Different Turkish governments have mouthed platitudes and postponed any real actions towards peace. There has never been any substantial move towards building trust and increasing tolerance between and within different ethnic groups. Successive Turkish governments did not show any understanding of the real sociological problems in Turkey. The PKK benefits from pre-existing problems of the Kurds and does not find it difficult to recruit new members. Thousands of young people join the PKK voluntarily every year. 
This shows that as long as exile conditions exist for the Kurds in Turkey, the PKK or similar organisations will not only exist but will thrive.

If there is to be any long-term and sustainable peace solution in Turkey, then multi-party and international involvement and guarantees are needed. Political and constitutional changes need to be adopted by the Turkish state. Only when this has happened, can societal changes follow. 


\section{References}

Abdi, Mustafa. 2015. 'External threats: the example of Kobane.' The Congress of Local and Regional Authorities of the Council of Europe, Strasbourg, 25 March 2015.

Akbaba, Yunus. 2014. “"6-7 Ekim Olayları” ve Çözüm Süreci.' Siyaset, Ekonomi ve Toplum Arastirmalari Merkezi (SETA). [Online, 23.10.2014]. Available at: http://setav.org/tr/6-7-ekim-olaylari-vecozum-sureci/perspektif/17648 [last accessed: 14.04.2015].

Al-Ali, Nadje. 2007. Gender, Diasporas and Post-War Conflict. In: Hazel Smith \& Paul Stares, eds. Diasporas in Conflict: Peace-Makers or Peace-Wreckers? Tokyo, New York \& Paris: United Nations University Press, 39-62.

Al-Monitor. 2013. 'Turkey's Kurds want explanation, apology for Roboski massacre.' In: Al-Monitor [Online, 28 December 2013]. Available at: http://www.almonitor.com/pulse/originals/2013/12/turkish-kurds-remain-estranged.html\# [accessed: 01.02.2016].

Amnesty International. 2016. 'Turkey: Indefinite 24-hour curfew, over 200,000 in danger' and 'Turkey: Onslaught on Kurdish areas putting tens of thousands of lives at risk.' Amnesty International website [Online, 11 and 21 January 2016]. Available at: https://www.amnesty.org/en/documents/EUR44/3178/2016/en/ and https://www.amnesty.org/en/latest/news/2016/01/turkey-onslaught-on-kurdish-areas-puttingtens-of-thousands-of-lives-at-risk/ [accessed: 24.01.2016].

Anderson, Benedict, ed. 1998. The Spectre of Comparisons, Nationalism, Southeast Asia, and the World. London, New York: Verso.

Anderson, Benedict. 2006. Imagined Communities: Reflections on the Origin and Spread of Nationalism. London, New York: Verso.

Barzani, Niyaz. 2014. 'Kurdish Diplomacy: A Success Story.' Rudaw [Online, 11 August 2014]. Available at: http://rudaw.net/english/opinion/11082014 [accessed: 21.11.2015].

Baser, Bahar. 2015a. Diasporas and Homeland Conflicts: A Comparative Perspective. Farnham: Ashgate.

Baser, Bahar. 2015b. 'Turkish-Kurdish conflict spills over into Europe.' The Conversation [Online, 16 October 2015]. Available at: http://theconversation.com/turkish-kurdish-conflict-spills-overinto-europe-47610 [accessed: 25.01.2016].

BBC News. 2016a. 'Af Orgutu: Guneydogu'daki operasyonlar toplu cezalandirmaya benziyor.' BBC Turkish News [Online, 21 January 2016]. Available at: http://www.bbc.com/turkce/haberler/2016/01/160121_amnesty_turkiye?ocid=socialflow_face book [accessed: 25.01.2016].

BBC News. 2016b. 'Syria: the story of the conflict.' BBC News [Online, 3 February 2016]. Available at: http://www.bbc.co.uk/news/world-middle-east-26116868 [accessed: 15.02.2016].

Bercovitch, Jacob. 2009. 'Mediation and Conflict Resolution.' In: Jacob Bercovitch, Victor Kremenyuk and William Zartman (eds.) Sage Handbook of Conflict Resolution. London: Sage, pp. 340-354. 
Besikci, Ismail. 2014. Presentation at the Public Forum: 'The Crisis of Middle East and Kurdish Question', Organised by the Centre for Turkey Studies (CEFTUS) in the House of Commons, 07.04.2014.

Bozarslan, Hamid. 2015. Presentation at the conference 'Rediscovering The Kurds in the Middle East: New Developments and Prospects.' Organised by the London Middle East Institute, SOAS, University of London [Online, 24 April 2015]. Available at: https://www.soas.ac.uk/Imei/events/24apr2015-the-kurds-in-the-middle-east-newdevelopments-and-prospects.html [accessed 07.05.2015].

Cakan, Seyhmus. 2015. 'Erdogan Says Turkey to Annihilate Kurdish Militants, 25 Killed.' Reuters [Online, 17 December 2015]. Available at: http://www.reuters.com/article/us-turkey-kurdsidUSKBNOU01B920151217 [accessed: 25.01.2016].

Candar, Cengiz. 2015. Presentation at the Westminster debate 'Kurdish Issue: Is Peace Still on the Table?' Organised by the Centre for Turkish Studies (CEFTUS), UK [Online, 27 October 2015]. Available at: http://ceftus.org/2015/10/31/ceftus-westminster-debate-kurdish-issue-is-peacestill-on-the-table/ [accessed: 02.02.2016].

CBC. 2016. 'Despite ISIS attacks, Turkey focused on 'the Kurdish problem.' CBC News [Online, 20 January 2016]. Available at: http://www.cbc.ca/news/world/turkey-isis-kurds-1.3408372 [accessed: 18.02.2016].

Channel Four News. 2014. 'Kurds in UK say; "Decriminalise the PKK!"' the UK Channel Four News. [Online, 9 September 2016]. Available at: http://www.you2repeat.com/watch/?v=MS5i_Swqj_8 [accessed: 24.01.2016].

Cohen, Robin. 1997. Global Diasporas: An Introduction. London: UCL P.

Connor, Walker. 1986. 'The Impact of Homelands upon Diasporas. In Gabriel Sheffer (ed.), Modern Diasporas in International Politics. New York: St. Martin's, 1986, pp. 16-46.

Constanze, Letsch. 2014. 'Their fight is our fight': Kurds rush from across Turkey to defend Kobani. The Guardian.[Online, 26 September 2014]. Available at: http://www.theguardian.com/world/2014/sep/26/kurds-rush-across-turkey-defend-kobani-isissyria [accessed: 24.03 .2015$]$.

Cumhuriyet. 2015. 'Hakan Fidan, 'Paris suikastını_MiT'teki bir grup yaptı' dedi - Cumhuriyet.' Cumhuriyet. [Online, 14 March 2015]. Available at:

http://www.cumhuriyet.com.tr/haber/turkiye/231251/Hakan_Fidan__Paris_suikastini_MiT_te ki_bir_grup_yapti_dedi.html [accessed: 25.01.2016].

Cumhuriyet. 2016. 'Türkiye'deki halkın yüzde 30'u başka bir ülke vatandaşı olmakistiyor.' Cumhuriyet. [Online, 16 February 2016]. Available at:

http://www.cumhuriyet.com.tr/haber/turkiye/482163/Turkiye_deki_halkin_yuzde_30_ u_baska_bir_ulke_vatandasi_olmak_istiyor.html\# [accessed: 18.02.2016].

Daglar, Ali. 2014. '6-7 Ekim'in acı bilançosu 50 ölü.' Hurriyet. [Online, 6.11.2014]. Available at: http://www.hurriyet.com.tr/gundem/27525777.asp [accessed: 14.04.2015].

Darweish, Marwan and Andrew Rigby. 2015. Popular Protest in Palestine: The Uncertain Future of Unarmed Resistance. Pluto Press. 
Demir, Emre. 2015. 'Le Monde publishes indictment claiming MIT involved in Paris murder of 3 PKK women.' Today's Zaman [Online, 24 July 2015]. Available at: http://www.todayszaman.com/anasayfa_le-monde-publishes-indictment-claiming-mi-tinvolved-in-paris-murder-of-3-pkk-women_394493.html [accessed: 25.01.2016].

Dogan, Yonca Poyraz. 2016. 'Çandar: Turkey might be torn apart if current Kurdish policy continues.' Today's Zaman [Online, 4 October 2011]. Available at: http://mobile.todayszaman.com/monday-talk_candar-turkey-might-be-torn-apart-if-currentkurdish-policy-continues_400600.html\# [accessed: 24.01.2016].

Economist. 2012. 'The Kurds and Turkey: Massacre at Uludere.' In: Economist. [Online, 9 January 2012]. Available at: http://www.economist.com/node/21556616 [accessed: 01.02.2016].

Ensaroglu, Yilmaz. 2013. 'Turkey's Kurdish Question and the Peace Process.' Insight Turkey, 15(2): 7-17.

Garmiany, Polla. 2015. 'Politicians, protesters in Germany condemn Turkey attacks on PKK.' Rudaw [Online, 26 July 2015]. Available at: http://rudaw.net/english/middleeast/turkey/260720153 [accessed: 25.01.2016].

Geerdink, Frederike. 2014. 'Kurds who became 'Village Guards' and fought PKK rebels in Turkey to be disbanded - but fear a betrayal.' Independent [Online, 16 February 2014]. Available at: http://www.independent.co.uk/news/world/europe/kurds-who-became-village-guards-andfought-pkk-rebels-in-turkey-to-be-disbanded-but-they-fear-a-9131095.html [accessed: 15.02.2016].

Gocek, Fatma Muge. 2011. The Transformation of Turkey: Redifining state and society from the Ottoman Empire to Modern Era. London. New York: I.B. Tauris.

Goel, Taylor. 2015. 'Three years after Roboski massacre in Turkey, justice is yet to be served.' Liberation [Online, 1 January 2015]. Available at: https://www.liberationnews.org/three-years-afterroboski-massacre-in-turkey-justice-is-yet-to-be-served/ [accessed: 01.02.2015].

Hamber, Brandon. 2015. 'Dealing with Painful Memories and Violent Pasts Towards a Framework for Contextual Understanding.' Berghof Foundation, Handbook Dialogue Series No. 11. Available at: http://www.berghoffoundation.org/fileadmin/redaktion/Publications/Handbook/Dialogue_Chapters/dialogue11_ha mber_lead.pdf [accessed: 16.02.2016].

Hamsici, Mahmut 2014. 'Ismail Besikci: Kurtler Milliyetci Olmalidir.' BBC Turkish Service [Online, 9 April 2014]. Available at: http://www.bbc.com/turkce/haberler/2014/04/140409_ismail_besikci_roportaj [accessed: 18.11.2015].

Harbom, Lotta and Peter Wallensteen. 2008. 'Dyadic Dimensions of Armed Conflict, 1946-2007.' Journal of Peace Research, 45(5), pp.697-710.

Hurriyet. 2015. 'We will not make you the president, HDP co-chair tells Erdoğan.' Hurriyet Daily News [Online, 17 March 2015]. Available at: http://www.hurriyetdailynews.com/Default.aspx?pagelD=238\&nID=79792\&NewsCatID=338 [accessed: 29.01.2016]. 
Jok, Madut. 2012. 'Sudan after Separation - New Approaches to a New Region.' South Sudan: Building a Diverse Nation, edited by Heinrich Böll Foundation and Toni Weis. Publication Series on Democracy, volume 28. Berlin, Germany: Heinrich-Boll-Stiftung: 58-67.

Karaca, Ekin. 2016. '6 Saldırı, 234 Ölü, Bir Görevden Alma, Sıfır İstifa.' Bianet [Online, 18 February 2016]. Available at: http://m.bianet.org/bianet/siyaset/172243-6-saldiri-234-olu-bir-gorevden-almasifir-istifa [accessed: 18.02.2016].

Lederach, John Paul. 1997. Building Peace: Sustainable Reconciliation in Divided Societies. New York: United States Institute of Peace.

Letsch, Constanze. 2016. 'Turkey says Kurds in Syria responsible for Ankara car bomb.' The Guardian [Online, 18 February 2016]. Available at: http://www.theguardian.com/world/2016/feb/18/explosion-hits-another-turkish-militaryconvoy-one-day-after-ankara-attack [accessed: 18.02.2016].

Loizides, Neophytos G. 2009. 'Elite Framing and Conflict Transformation in Turkey.' Parliamentary Affairs, 62(2): 278-297.

Marcus, George. 1995. 'Ethnography in/of the World System: The Emergence of Multi-sited Ethnography.' In: Annual Review of Anthropology, 24: 95-117.

Palmer, Colin. 1998. 'Defining and Studying the Modern African Diaspora.' Perspectives 36.

Philips, David L. 2015. The Kurdish Spring: A New Map of the Middle East. New Brunswick: Transaction Publishers.

Pitel, Laura 2016. 'Turkey in crisis: Renewal of conflict with Kurdish militants is accompanied by a highly toxic political and media climate.' Independent [Online, 19 January 2016]. Available at: http://www.independent.co.uk/news/world/middle-east/turkey-in-crisis-renewal-of-conflictwith-kurdish-militants-is-accompanied-by-a-highly-toxic-a6821941.html [accessed: 24.01.2016];

Pope, Hugh. 2014. 'Why Syria's disaster threatens a war in Turkey.' the Guardian. [Online, 10.10.2014]. Avaibale at: http://www.theguardian.com/commentisfree/2014/oct/10/syria-disaster-warturkey-isis-pkk [last accessed: 14.04.2015].

Rosenberg, Shawn W. and Gadi Wolfsfeld. 1977. 'International conflict and the problem of arbitration.' Journal of Conflict Resolution 21(1): 75-103.

RT, 2016. 'Ankara blast: Convenient excuse for Erdogan to hunt Kurds 'everywhere'?' RT Com [Online, 18 February 2016]. Available at: https://www.rt.com/op-edge/332834-ankara-blast-erdogan-kurds/ [accessed: 18.02.2016].

Safran, William. 1991. 'Diasporas in Modern Societies: Myths of Homeland and Return.' Diaspora 1: 8399.

Ramsbotham, Oliver, Tom Woodhouse and Hugh Miall. 2011. The Contemporary Conflict Resolution: The prevention, management and transformation of deadly conflicts. 3rd Edition, Cambridge: Polity Press. 
Sanchez, Raf. 2016. 'Turkish government co-operated with al-Qaeda in Syria, says former US ambassador.' The Telegraph [Online, 12 September 2014]. Available at: http://www.telegraph.co.uk/news/worldnews/europe/turkey/11093478/Turkish-governmentco-operated-with-al-Qaeda-in-Syria-says-former-US-ambassador.html [accessed: 24.01.2016].

Schiller, G. Nina and Fouron Eugene Georges, eds. 2001. George Woke Up Laughing: Long-Distance Nationalism and the Search for Home. Durham and London: Duke University Press.

Schiller, G. Nina. 2005. Long-Distance Nationalism. In: Melvin Ember, Carol R. Ember and lan Skoggard, eds. Encyclopedia of Diasporas Immigrant and Refugee Cultures Around the world: Volume I Overviews and Topics. New York: Springer, pp. 570-580.

Sheffer, Gabriel. 2002. Diaspora Politics: At Home Abroad. New York: Cambridge University Press.

Snyder, Anna. 2015. 'A Gendered Analysis of Refugee Peacebuilding: Transnational Networks for Peace.' Review of Social Studies (RoSS), 2(1): 1-24.

Sumbeiywo, General Lazaro. 2008. To Be A Negotiator: Strategies and Tactics. Lazaro Sumbeiywo and the Mediation Support Project, Center for Security Studies, ETH Zurich and swisspeace, Bern.

Tas, Latif. 2013a. 'Resolving Family Disputes in the Gurbet: The Role of Kurdish Peace Committee and Roj Women.' Onati Socio-Legal Series, 3(6): 1111-1135.

Tas, Latif. 2013b. 'One State, Plural Options: Kurds in the UK'. The Journal of Legal Pluralism and Unofficial Law, 45(2): 167-189.

Tas, Latif. 2014. Legal Pluralism in Action: Dispute Resolution and Kurdish Peace Committee . Farnham: Ashgate.

Tas, Latif. 2015. 'What kind of peace? The case of the Turkish and Kurdish peace process.' Open Democracy [Online, 9 July 2015]. Available at: https://www.opendemocracy.net/latif-tas/whatkind-of-peace-case-of-turkish-and-kurdish-peace-process [accessed: 09.07.2015].

Tas, Latif. 2016. 'How International Law Impacts on Statelessness and Citizenship: the case of Kurdish nationalism, conflict and peace.' Cambridge University Journal, International Journal of Law in Context, 12(1), pp.41-82.

Telgraf. 2016. 'Davutoglu arka kapidan kacti.' Telgraf Newspaper [Online, 18.01.2016]. Available at: http://www.telgraf.co.uk/davutoglu-arka-kapidan-kacti-videofoto.html [accessed: 25.01.2016].

Tezcur, Gunes M. 2013. 'Prospects for Resolution of the Kurdish Question: A Realist Perspective.' Insight Turkey, 15(2).

Tezcur, Gunes M. 2010. 'When democratization radicalizes: the Kurdish nationalist movement in Turkey.' Journal of Peace Research, 47(6): 775-789.

The UK Green Party. 2016. 'Natalie Bennett: Turkey must show respect for internationally accepted human rights'. Greenparty website [Online, 24 January 2016]. Available at: https://www.greenparty.org.uk/news/2016/01/24/natalie-bennett-turkey-must-show-respectfor-internationally-accepted-human-rights/ [accessed: 24.01.2016]. 
Tisdall, Simon. 2016. 'Ankara Bombing: Blaming Kurds Suits Erdogan's Political Ends.' The Guardian. [Online, 18 February 2016]. Available at: http://www.theguardian.com/world/2016/feb/18/ankara-bombing-blaming-kurds-suitserdogans-political-ends?CMP=share_btn_fb [accessed: 18.02.2016].

Today's Zaman. 2015. 'KCK head sets out 6 conditions for laying down arms.' Today's Zaman [Online, 16 March 2015]. Available at: http://www.todayszaman.com/anasayfa_kck-head-sets-out-6conditions-for-laying-down-arms_375418.html [accessed: 25.01.2016].

Tölölyan, Khachig. 1994. 'Diasporama.' Diaspora 3: 235-235.

Turkone, Mumtazer. 2009. 'Good things are going to happen.' Today's Zaman [Online, 16 May 2009]. Available at: http://www.todayszaman.com/columnist/mumtazer-turkone/good-things-aregoing-to-happen_175466.html [accessed: 28.01.2016].

Ustundag, Gulten. 2016. 'Interior Minister acknowledges 'ethnic group code' given to Turkey's minorities.' Today's Zaman [Online, 15 February 2016]. Available at: http://mobile.todayszaman.com/national_interior-minister-acknowledges-ethnic-group-codegiven-to-turkeys-minorities_412405.html [accessed: 16.02.2016].

Vali, Abbas. 2015. Presentation at the conference 'Rediscovering The Kurds in the Middle East: New Developments and Prospects.' Organised by the London Middle East Institute, SOAS, University of London [Online, 24 April 2015]. Available at: https://www.soas.ac.uk/Imei/events/24apr2015the-kurds-in-the-middle-east-new-developments-and-prospects.html [accessed: 7.05.2015].

Wessels, Michael G. 1998. 'Children, Armed Conflict, and Peace.' Journal of Peace Research 35(5): 635646.

Yavuz, M. Hakan. 2009. Secularism and Muslim Democracy in Turkey. Cambridge: Cambridge University Press.

Yavuz, M. Hakan and Nihat Ali Ozcan. 2007. 'Crisis in Turkey: The Conflict of Political Languages. Middle East Policy, 14(3): 118-135.

Zartman, I. William. 2007. Peacemaking in international conflict: Methods, Technics. Washington: United States Institute for Peace. 